\title{
Adverse Effect of Buprofezin and Acephate on Enzymatic Activities in NPK Amended and Unamended Cotton Soils
}

\author{
Maddela Naga Raju ${ }^{1, *}$ and Kadiyala Venkateswarlu ${ }^{2}$ \\ ${ }^{1}$ Universidad Estatal Amazonica, Puyo, Ecuador - 160150. \\ ${ }^{2}$ Department of Microbiology, Sri Krishnadevaraya University, Anantapur, India - 515055 \\ *Corresponding author: mnraju8875@gmail.com
}

Copyright (C) 2013 Horizon Research Publishing All rights reserved.

\begin{abstract}
A thiadiazine compound, buprofezin, and an organophosphorous insecticide, acephate, singly, were assessed for their nontarget effects on activities of proteases, urease and acid phosphatase in NPK (nitrogen, phosphorous and potassium)-fertilizer amended and unamended cotton soils. The studied enzyme activities were adversely affected by the insecticides above 5 or $7.5 \mu \mathrm{g} \mathrm{g}^{-1}$ concentrations. Additionally, activities were declined after three applications of insecticides. Therefore, the results of the present study clearly indicate that the soil application of buprofezin or acephate at higher rates and repeated applications greatly affected the activities of studied enzymes in unamended or NPK-amended soils.
\end{abstract}

Keywords Buprofezin, acephate, nontarget effects, soil enzymes, nutrient amendments

\section{Introduction}

In modern agriculture, it has become a common trend to apply different groups of pesticides, either simultaneously or in succession, for effective control of a variety of pests. Pesticide applications at recommended rates have little or no effect on enzyme activity in soils [1-5]. But, soil enzyme activities [6-9] and individual microorganisms [10] are usually affected when pesticides are applied to soil at higher than recommended rates over long periods. In contrast, soil application of insecticides stimulated soil microbiological activities [11]. Thus, monitoring of the pedosphere using the methods based on enzymatic tests enables a complex assessment of the changes in the soil environment under the influence of anthropogenic factors [12].

There is a serious concern about the vast economic damage caused to cotton by many insect pests such as Amrasca biguttula (Cotton Jassid), Bemisia tabaci (Cotton Whitefly), Aphis gossypii (Cotton Aphid), and Thrips tabaci (Cotton Thrips), because cotton is an important fiber yielding crop of global importance which is grown in tropical and subtropical regions of more than 80 countries the world over. For the effective control of these insect pests on cotton, several insecticides are used on need basis. In particular, the two insecticides, buprofezin (Applaud $\left.{ }^{\circledR}\right)$ and acephate $\left(\right.$ Hythene $\left.{ }^{\circledR}\right)$ are widely used in the recent years to combat major insect pests of cotton. More importantly, due to high hydrophobicity ( $\log \mathrm{P}=4.31)$, buprofezin is easily adsorbed onto soil particles; strong soil adsorption is sometimes contributed to persistence of the compound in soils. Additionally, for improving soil fertility, the agricultural soils are generally amended with NPK-fertilizers. The average per-hectare use of NPK fertilizers on cotton is $120-80-60 \mathrm{~kg} \mathrm{ha}^{-1}$, respectively. In this direction, several studies were conducted to evaluate the effects many pesticides on soil populations of bacteria, fungi and actinomycetes, and soil enzymes after single or repeated applications [5, 13-16]. However, virtually no information is available in the literature on nontarget effects of the two widely used insecticides, buprofezin and acephate, towards microbial activities in soil. In the present investigation, an attempt has, therefore, been made to assess the impact of single or repeated applications of buprofezin and acephate on proteases, urease and acid phosphatase activities in unamended and NPK-fertilizer-amended soils.

\section{Materials and Methods}

\subsection{Soil Collection}

Soils with a known history of insecticide (buprofezin or acephate) use, were collected from fields (inherently very fertile) under cultivation of cotton at Nandyal, a semi-arid region of Andhra Pradesh, India, to a depth of $12 \mathrm{~cm}$.

\subsection{Insecticides and Fertilizers Selected in the Present Study}

Two insecticides, buprofezin (2-tert-butylimino-3-isopro pyl-5-phenyl-1,3,5-thiadiazinan-4-one) and acephate (O,S-dimethyl acetyl phosphoramidothioate), were selected for the present investigation in view of their extensive and 
intensive usage in Indian agriculture, in general, and Nandyal division, in particular, for control of major insect pests on cotton. Stock solutions of commercial formulations of buprofezin (Applaud, 25\% SC, Rallies India Limited, Mumbai) and acephate (Hythene, 75\% SP, Hyderabad Chemicals Limited, Hyderabad) were prepared in sterile distilled water for amendment to soil samples. The mineral fertilizer urea, calcium perphosphate and potassium were used at a rate of $120 \mathrm{~kg} \mathrm{~h}^{-1} \mathrm{~N}, 80 \mathrm{~kg} \mathrm{~h}^{-1} \mathrm{P}_{2} \mathrm{O}_{5}$ and $60 \mathrm{~kg} \mathrm{~h}^{-1}$ $\mathrm{K}_{2} \mathrm{O}$.

\subsection{Effect of Selected Insecticides on Soil Enzyme Activities}

Aliquots $(0.5 \mathrm{~mL})$ from stock solutions of the insecticides, prepared in water, were applied to the surface of $5 \mathrm{~g}$ soil samples contained in test tubes $(25 \times 200 \mathrm{~mm})$ as followed by Lethbridge and Burns [17]. The final concentrations (on $\mathrm{w} / \mathrm{w}$ basis) of each insecticide included $2.5,5.0,7.5$ and 10.0 $\mu \mathrm{g} \mathrm{g}^{-1}$ soil, which correspond to $0.25,0.5,0.75$ and $1 \mathrm{~kg} \mathrm{ha}^{-1}$, respectively [18]. These concentrations were chosen because of the fact that the field application dose of the selected insecticides range from $\sim 0.3$ to $0.6 \mathrm{~kg} \mathrm{ha}^{-1}$. Besides insecticide treatment, soil samples in one set were amended with N-P-K fertilizer at a rate of 120-80-60 kg ha respectively. But, soil samples in second set were treated with insecticides only. The soil samples receiving only 0.5 $\mathrm{mL}$ water served as controls. All the treatments including controls were maintained at $60 \%$ water-holding capacity, and incubated at $28 \pm 4{ }^{\circ} \mathrm{C}$. After 3 days of incubation (i.e., single application), triplicate soil samples were withdrawn for the assay of proteases [19], urease [20] and acid phosphatase [21] activities. Likewise, enzyme activities in soil samples were also determined after two (15 days incubation) and three (30 days incubation) repeated applications of insecticides separately.

\subsection{Assay of Selected Soil Enzymes}

\subsubsection{Proteases}

Activities of proteases in soil samples were determined by the method of Speir and Ross [19]. Soil samples (5 g) were incubated for $24 \mathrm{~h}$ at $30{ }^{\circ} \mathrm{C}$ with $10 \mathrm{~mL}$ of $0.1 \mathrm{M}$ tris [2-amino-2(hydroxyl methylmethyl)-propane-1:3-diol; $\mathrm{pH}$ $7.5]$ containing sodium caseinate $(2 \% \mathrm{w} / \mathrm{v})$. Four milliliters of aqueous solution $(17.5 \% \mathrm{w} / \mathrm{v})$ of trichloro acetic acid was then added, and the mixture was centrifuged. A suitable aliquot of the supernatant was treated with $3 \mathrm{~mL}$ of $1.4 \mathrm{M}$ $\mathrm{Na}_{2} \mathrm{CO}_{3}$ followed by the addition of $1 \mathrm{~mL}$ Folin-Ciocalteau reagent $(33.3 \% \mathrm{v} / \mathrm{v})$. The blue color was read after $30 \mathrm{~min}$ at $700 \mathrm{~nm}$ in a spectrophotometer. Tyrosine was used as a standard. The activities of proteases were expressed in terms of milligrams of tyrosine released per $\mathrm{g}$ of soil per $24 \mathrm{~h}$ (mg tyrosine $\mathrm{g}^{-1} 24 \mathrm{~h}^{-1}$ ).

\subsubsection{Urease}

Urease activity in untreated and insecticide- and/or fertilizer-treated soil samples (5 g) was determined by incubating for $30 \mathrm{~min}$ at $30^{\circ} \mathrm{C}$ with $4 \mathrm{~mL}$ of $0.2 \mathrm{M}$ sodium phosphate buffer $(\mathrm{pH} 7.0)$ and $1 \mathrm{~mL}$ of $1 \mathrm{M}$ urea (prepared in sodium phosphate buffer). Ten milliliters of aqueous solution of potassium chloride ( $2 \mathrm{M}$ ) was then added, and the mixture was kept at $4{ }^{\circ} \mathrm{C}$ for $10 \mathrm{~min}$ and centrifuged [20]. A suitable aliquot of the supernatant was treated with $0.5 \mathrm{~mL}$ of Nessler's reagent followed by the addition of $3.5 \mathrm{~mL}$ of distilled water. The red color was read at $495 \mathrm{~nm}$ in an Elico digital spectrophotometer. By using ammonium sulphate as a standard, urease activity was expressed in terms of milligrams of ammonical nitrogen released per $\mathrm{g}$ of soil per $30 \mathrm{~min}\left(\mathrm{mg} \mathrm{NH}_{4}{ }^{+}-\mathrm{N}\right.$ released $\left.\mathrm{g}^{-1} 30 \mathrm{~m}^{-1}\right)$.

\subsubsection{Acid Phosphatase}

Acid phosphatase activity in soils was determined following the method of Tabatabai and Bremner [21]. Soil samples $(5 \mathrm{~g})$ were incubated at $37^{\circ} \mathrm{C}$ for $30 \mathrm{~min}$ with $15 \mathrm{~mL}$ of enzyme buffer (100 mM sodium acetate of $\mathrm{pH} 5.5$ containing $10 \mathrm{mM}$ magnesium chloride) and $5 \mathrm{~mL}$ of $0.03 \mathrm{M}$ $p$-nitrophenyl phosphate. The mixture was kept on ice for 20 min and centrifuged. A suitable aliquot of the supernatant was treated with $3 \mathrm{~mL}$ of enzyme buffer, and was kept on ice for $20 \mathrm{~min}$. Then, $1 \mathrm{~mL}$ of aqueous solution of $5 \mathrm{mM}$ calcium chloride and $4 \mathrm{~mL}$ of $0.5 \mathrm{M}$ sodium hydroxide were added to the above mixture. The yellow color was read at 405 $\mathrm{nm}$ in an Elico digital spectrophotometer. $p$-nitrophenol (PNP) was used as a standard, and the acid phosphatase activity was expressed as milligrams of PNP released per $g$ of soil per $30 \mathrm{~m}\left(\mathrm{mg}\right.$ PNP g $\left.\mathrm{g}^{-1} 30 \mathrm{~m}^{-1}\right)$.

\section{Results and Discussion}

\subsection{Nontarget Effects of Buprofezin and Acephate on Proteases}

The data on protease activity in soil as influenced by buprofezin and acephate are shown in figures $1 \mathrm{a}$ and $\mathrm{c}$, respectively. Concentration up to $7.5 \mu \mathrm{g}$ of buprofezin $\mathrm{g}^{-1}$ soil was either nontoxic or stimulatory to protease activity in soil after single application (Figure 1a). Furthermore, highest activity of the enzyme was noticed in soil that has received buprofezin at $5 \mu \mathrm{g} \mathrm{g}^{-1}$ soil. However, activity was rapidly declined at the highest concentration of buprofezin used (10 $\left.\mu \mathrm{g} \mathrm{g}^{-1}\right)$. Interestingly, the stimulatory effect of buprofezin continued even after two repeated applications. But, the activity was slightly declined after three applications of the insecticide to soil. Thus, activities were increased over time for some extent, but later declined. On the other hand, the response of proteases to acephate was very similar to that of buprofezin (Figure 1c). Acephate, even at $7.5 \mu \mathrm{g} \mathrm{g}^{-1}$ concentration, could stimulate $(51 \%)$ protease activity in soil after single application. Similar effects have been noticed in many studies conducted earlier. According to Rangaswamy 
et al. (1994), monocrotophos, cypermethrin and fenvalerate even at $10 \mathrm{~kg} \mathrm{ha}^{-1}$ were stimulatory to protease activity; however, but the enzyme activity was negatively affected by the three insecticides at $12.5 \mathrm{~kg} \mathrm{ha}^{-1}$. Among studies in which different xenobiotics were individually tested, those that generally caused the greatest inhibition in proteases activity in soil were fenthion [22], cartap hydrochloride [23], metsulfuron-methyl [24], mancozeb [25] etc. Contrary to the results obtained in the present study, phenmedipham even at $10 \mathrm{mg} \mathrm{kg}^{-1}$ did not affect protease activity in soil [26]. Thus, the available literature and data of the present investigation clearly suggest that proteases respond negatively to most pesticides at concentrations above the field application rates.

The data on behavior of protease in soil that has received NPK-fertilizer upon insecticide treatment are shown in figures $1 \mathrm{~b}$ and c. Single application of buprofezin, up to 7.5 $\mu \mathrm{g} \mathrm{g}^{-1}$, was either nontoxic or stimulatory (17\%) to protease

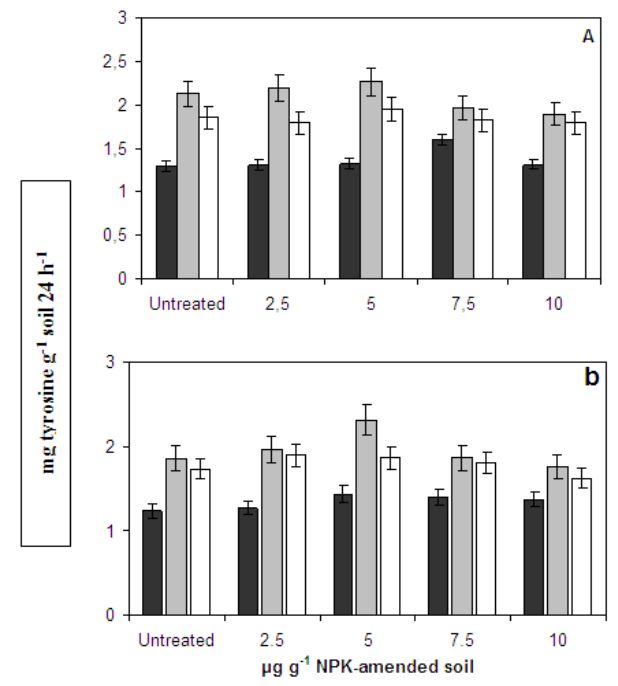

Single applications Two applications in amended soil. The insecticide only at $10 \mu \mathrm{g} \mathrm{g}^{-1}$ soil could inhibit $(27 \%)$ the activity of protease (Figure 1b). As with unamended soil, two applications of buprofezin also stimulated the protease activity in NPK-fertilizer amended soil. However, the enzyme activity markedly declined after three repeated applications. On the other hand, acephate could also influence the proteases similar to buprofezin (Figure 1d). Acephate, up to $7.5 \mu \mathrm{g} \mathrm{g}^{-1}$ and two repeated applications, could stimulate the protease activity. However, upon three repeated applications at $10 \mu \mathrm{g} \mathrm{g}^{-1}$ soil, the enzyme activity was adversely affected in amended soil. Renella et al. [27] performed long-term field experiments in which soil, contaminated with $\mathrm{Mn}-\mathrm{Zn}$ - or Cd-Ni-rich sludge, was incorporated at two different rates. Protease activity was generally more pronounced in all the sludge-amended soils than in control soils.
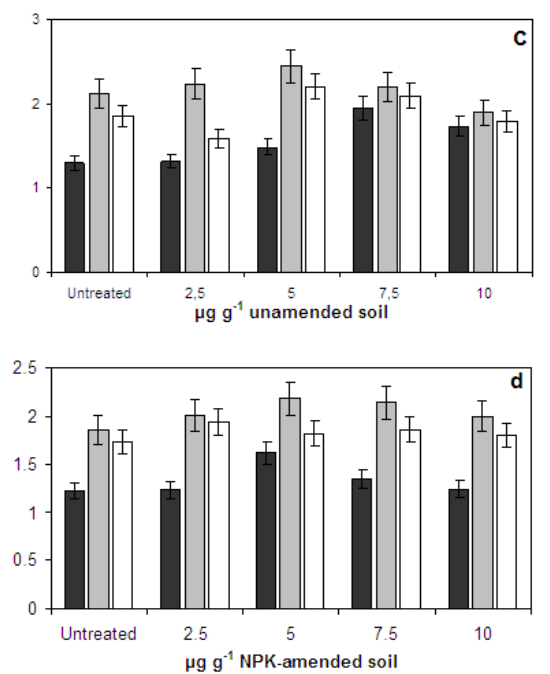

Figure 1. Effect of single and repeated applications of buprofezin (a, b) and acephate (c, d) on protease activity

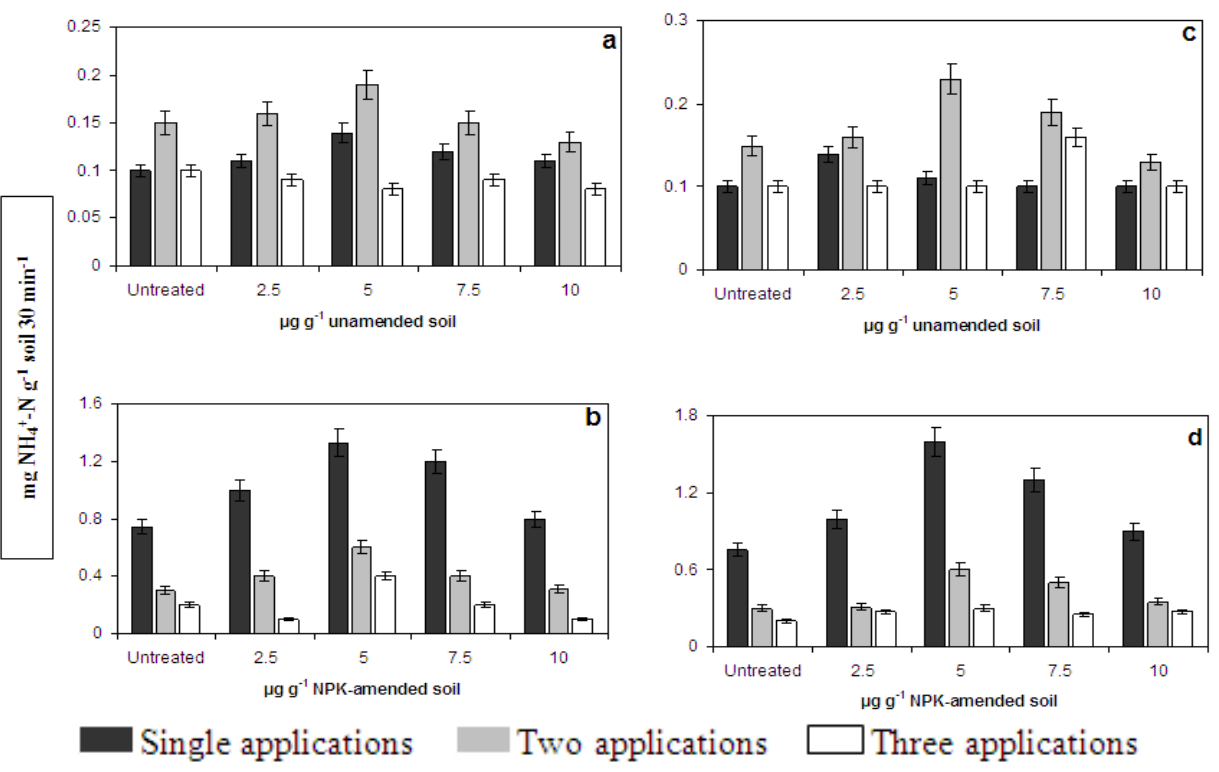

Figure 2. Effect of single and repeated applications of buprofezin $(a, b)$ and acephate (c, d) on urease activity 


\subsection{Nontarget Effects of Buprofezin and Acephate on Urease}

Soil urease, a vital enzyme in the nitrogen turnover, has been studied under the impact of single or repeated applications of buprofezin or acephate by determining the ammonical nitrogen released from urea, and the results are presented in figure 2. Buprofezin, at concentrations ranging from 2.5 to $7.5 \mu \mathrm{g} \mathrm{g}^{-1}$ soil was either stimulatory or nontoxic to urease (Figure 2a). Surprisingly, even $7.5 \mu \mathrm{g}$ buprofezin $\mathrm{g}^{-1}$ soil did not affect urease in soil. However, optimum activity $(40 \%)$ was recorded in soil that has received $5 \mu \mathrm{g} \mathrm{g}^{-1}$ of the tested insecticide. The activity was stimulated (25-45\%) even after two applications of buprofezin to the soil. However, urease activity decreased by $30-50 \%$ after three repeated applications of the insecticide to soil. But, acephate was much more toxic to urease than buprofezin (Figure $2 \mathrm{c}$ ). Though the activity was stimulated (7-53\%) at 2.5 and $5 \mu \mathrm{g} \mathrm{g}^{-1}$, it was affected adversely (20-40\%) at 7.5 and $10 \mu \mathrm{g}$ acephate $\mathrm{g}^{-1}$ soil. Again, activity was stimulated after two repeated applications of acephate, but was inhibited after three applications of acephate to soil. Thus, two insecticides did stimulate the enzyme activity with time upto some extent, later did inhibit the enzyme activities. Available evidences also suggest that ureolytic microorganisms isolated from the soil were inhibited by the OP pesticides to a greater or lesser extent, but the development of tolerance was common $[17,28]$. Even $100 \mathrm{mg}$ fenamiphos $\mathrm{kg}^{-1}$ soil was not toxic to urease [29]. Small increases were measured for ureases in soils treated with glyphosate and paraquat [8] and chlorimuron-ethyl and Furadan [30]. Nevertheless, long-term treatment and higher rates of pesticides did adversely affect the urease activity in soils [6, 24, 31-34].

The response of urease was quite interesting and surprising in soil that has received both insecticides and NPK amendments. Urease activity was significantly enhanced (7-77\%) by the single application of buprofezin at all four concentrations tested $\left(2.5-10 \mu \mathrm{g} \mathrm{g}^{-1}\right)$ in NPK-amended soil (Figure $2 \mathrm{~b}$ ). Most pronounced activity was noticed in soil that was treated with the insecticide at $5 \mu \mathrm{g} \mathrm{g}^{-1}$ soil. Furthermore, repeated applications of selected insecticides to soil amended with NPK-fertilizer caused reduction (70-90\%) in urease activity greatly. In fact, urease activity was decreased by more than $50 \%$ after two applications over the activity recorded after single application. Again, the lowest activity was noticed after three repeated applications. In addition, soil urease did respond to acephate very similar to that of buprofezin in amended soil (Figure 2d). These results are similar to the findings reported in the literature. Ingram et al. [35] applied diazinon and imidacloprid to lawns for insect control simultaneously with nitrogenous fertilizer such as urea and observed that diazinon briefly, but significantly, reduced urease activity in blue grass sod. Co-application of imidacloprid and urea appeared to increase urease activity in soil and sod. Likewise, soil urease activity was adversely affected in the presence of high level of mineral fertilization ([36], Mn-Zn- or Cd-Ni-rich sludge [27], Ag and Hg [37]. Also, decomposition rate of pesticides has been greatly declined by nitrogen and phosphorous [38] and Roundup
Ultra [39]in soil. Studies by many authors [40-42] indicated that an increase in the concentration of hydrogen ions in soil has a negative effect on its enzyme activity.

\subsection{Nontarget Effects of Buprofezin and Acephate on Acid Phosphatase}

The nontarget effects of buprofezin and acephate on acid phosphatase activity in soils were determined by the release of PNP from $p$-nitrophenyl phosphate and results are shown in figure 3. It is evident from the result that after single application, buprofezin stimulated (29-186\%) the enzyme activity at concentration ranging from 2.5 to $7.5 \mu \mathrm{g} \mathrm{g}^{-1}$ soils, with an optimum activity at $5 \mu \mathrm{g} \mathrm{g}^{-1}$ soil (Figure 3a). However, the insecticide is toxic (29\% reduction in activity) to the enzyme at $10 \mu \mathrm{g} \mathrm{g}^{-1}$ soil. Also, activity of the enzyme was stimulated (11-65\%) even after two applications of buprofezin to soil. But, after three applications, the enzyme activity declined (64-100\%) drastically. Like other two enzymes, activities of acid phosphatase were also decreased with time. Similarly, acephate at field application rate was nontoxic or stimulatory to acid phosphatase activity in soil (Figure 3c). The accumulation of PNP was more striking (43\% stimulation) at the $5 \mu \mathrm{g} \mathrm{g}^{-1}$ soil level. The highest level of $10 \mu \mathrm{g} \mathrm{g}^{-1}$ soil was inhibitory (29\%) to the enzyme. Furthermore, activity was stimulated after two applications of acephate to the soil, but was declined after three repeated applications.

The extent of acid phosphatase activity in NPK-amended soil samples under the impact of buprofezin and acephate was also determined and the results were very similar to those observed with soil samples that not received the fertilizers (Figure $3 \mathrm{~b}$ and d). Both the insecticides profusely stimulated (up to $233 \%$ ) the enzyme activity to an optimal level at $5 \mu \mathrm{g} \mathrm{g}^{-1}$ soil. Nonetheless, the enzyme activity was inhibited greatly at higher rates of the two insecticides and, particularly, after three repeated applications. Similarly, Omar and Abdel-Sater [43] reported that brominal and selecron promoted acid phosphatase activity in soil at field application rates after some incubation periods, but the enzyme activity was less at the higher application doses.

Surprisingly, Yao et al. [44] found strong negative influence on phosphatase activity in soil treated with a new pesticide, acetamiprid, applied at normal field concentration $\left(0.5 \mathrm{~m} \mathrm{~kg}^{-1}\right)$ and at high concentrations (5 and $\left.50 \mathrm{mg} \mathrm{kg}^{-1}\right)$. Furthermore, according to Sikora et al.[45], over $40 \%$ of the insecticide treated fence row soils which had no previous exposure to insecticides showed higher acid phosphatase activity. Likewise, a general inhibitory effect was observed for phosphatase in the presence glyphosate [8], propiconazole [46], chlorothalonil [28], chlorpyrifos [47], Ridomil Gold Plus copper [48], atrazine [6], a fungicide Swing Top 183 SC [33], benomyl and captan [49], fluchloralin, methabenzthiasuron, metoxuron, 2,4-D and isoproturon [50] However, either fenamiphos [51] or flopet and captafol [52] did not influence the phosphatase activity in soil. In contrast, stimulation in phosphatase activity under the influence of paraquat, trifluralin, glyphosate and atrazine has been reported by Hazel and Greaves [53].. 

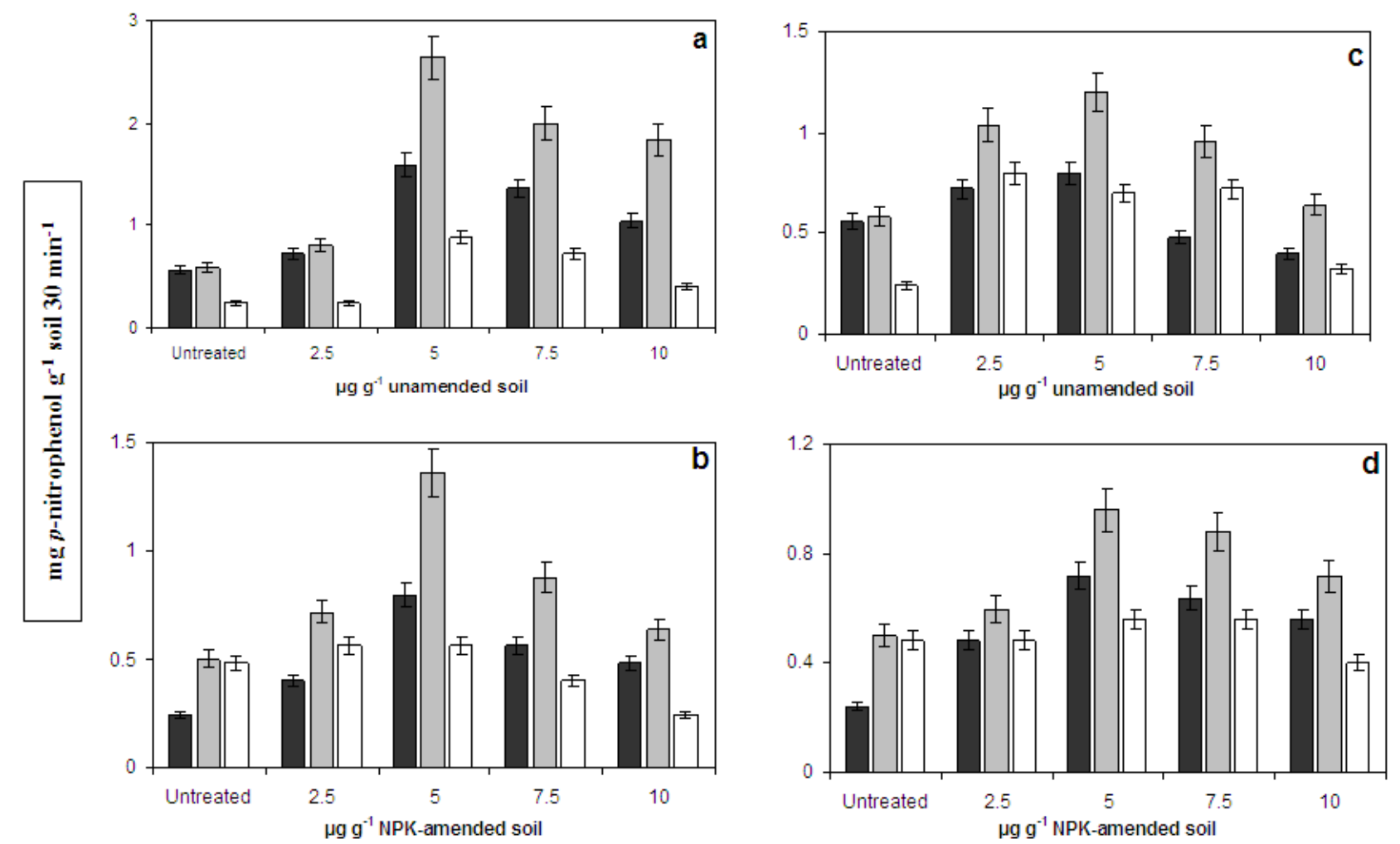

- Single applications $\square$ Two applications $\square$ Three applications

Figure 3. Effect of single and repeated applications of buprofezin $(a, b)$ and acephate (c, d) on acid phosphatase activity

\section{Conclusion}

The results of the present investigation concerned with the insecticide-microflora interactions in cotton soils clearly reveal that two and three repeated applications of the insecticides caused adverse effects on measured enzymatic activities in NPK-amended and unamended soils. Also, soil application of buprofezin or acephate at higher rates greatly affected the activities of several enzymes in unamended or NPK-amended soils.

\section{Acknowledgements}

We wish to thank Dr. S. Imthiyaz Ahamed, Principal, National P.G. College, Nandyal for providing lab facilities and encouraging us through out this study.

\section{REFERENCES}

[1] Ladd, J.N., 1985. Soil enzymes. In: Vaughan D, Malcolm RE (eds.). Soil Organic Matter and Biological Activity. Martinus Nijhoff, Boston. pp. 175-221.

[2] Schäffer, A., 1993. Pesticide effects on enzyme activities in the soil ecosystem. In: Bollag JM, Stotzky G (eds) Soil
Biochemistry. Marcel Dekker, New York, pp. 273-340.

[3] Nannipieri, P., 1994. The potential use of soil enzymes as indicators of productivity, sustainability and pollution. In: Pankhurst CE, Doube BM, Gupta VVSR, Grace PR (eds.) Soil Biota: Management in Sustainable Farming Systems. CSIRO Melbourne. pp. 238-244.

[4] Rangaswamy, V., Reddy, B.R., Venkateswarlu, K., 1994. Activities of dehydrogenase and protease in soil as influenced by monocrotophos, quinalphos, cypermethrin and fenvalerate. Agric Ecos Environ 47:319-326.

[5] Dick, R.P., 1997. Soil enzyme activities as integrative indicators of soil health. In: Pankhurst CE, Doube BM, Gupta VVSR (eds.). Biological Indicators of Soil Health. CAB International, Wallingford, UK. pp. 121-156.

[6] Voets, J.P., Meerschman, P., Verstraete, W., 1974. Soil microbiological and biochemical effects of long term atrazine applications. Soil Biol Biochem 6:149-152

[7] Rai, J.P.N., 1992. Effect of long-term 2,4-D application on soil microbial populations. Biol Fertil Soils 13:427-431.

[8] Sannino, F., Gianfreda, L., 2001. Pesticide influence on soil enzymatic activities. Chemosphere 45:417-425.

[9] Megharaj, M., 2002. Heavy pesticide use lowers soil health. Kondinin Landcare.

http://www.clw.csiro.au/publications/farming_ahead/2002/p 3738_FA121_JAN02.pdf

[10] Bhaskar, M., Sreenivasulu, C., Venkateswarlu, K., 1994. 
Nontarget effects of monocrotophos and quinalphos towards Anabaena torulosa isolated from rice soil. Microbiol Res 149:395-400.

[11] Rangaswamy, V., Venkateswarlu, K., 1993. Ammonification and nitrification in soils, and nitrogen fixation by Azospirillum sp. As influenced by cypermethrin and fenvalerate. Agric Ecos Environ 45:311-317.

[12] Taylor, J.P., Wilson, B., Mills, M.S., Burns, R.G., 2002. Comparison of microbial number and enzymatic activities in surface soils and subsoil using various techniques. Soil Biol Biochem 34:387.

[13] Burns, R.G., 1978. Soil Enzymes. Academic Press. New York, pp. 370.

[14] Greaves, M.P., Malkones, H.P., 1980. Effect on soils microflora. In: Interaction between Herbicides and the Soil. Hance RJ, (ed.). Academic Press, Inc., London. pp. 223-253.

[15] Wyszkowska, J., Kucharski, J., 2004. Biochemical and physicochemical properties of soil contaminated with herbicide. Triflurotex 250 EC. Pol J Environ Stud $3: 223-231$.

[16] Gonzalez, M.G., Gallardo, J.F., Gomez, E., Masciandaro, G., Ceccanti, B., Pajares, S., 2007. Potential universal applicability of soil bioindicators: evaluation in three temperate ecosystems. C1. Suelo (Argentina). 25:151-158.

[17] Lethbridge, G., Burns, R.G., 1976. Inhibition of soil urease by organophosphorous insecticides. Soil Biol Biochem 8:99-102.

[18] Anderson, J.R., 1978. Pesticide effects on non-target soil microorganisms. In: Hill IR, Write SJL (eds.), Pesticide Microbiology. Academic Press, London, pp. 313-533.

[19] Speir, T.W., Ross, D.J., 1975. Effects of storage on the activities of protease, urease, phosphatase and sulphatase in three soils under pasture. New Zea J Sci 18:231-237.

[20] Zantua, M.I., Bremner, J.M., 1975. Comparison of methods of assaying urease activity in soils. Soil Biol Biochem 7:291.

[21] Tabatabai, M.A., Bremner, J.M., 1969. Use of $p$-nitrophenyl phosphate for assay of soil phosphatase activity. Soil Biol Biochem 1:301-307.

[22] Newell, S.Y., Cooksey, K.E., Fell, J.W., Master, I.M., Miller, C., Walter, M.A., 1981. Acute impact of an organophosphorus insecticide on microbes and small invertebrates of a mangrove estuary. Arch Environ Cont Toxicol 10:427-435.

[23] Endo, T., Kuska, T., Tan, N., Sakai, M., 1982. Effects of the Insecticide Cartap Hydrochloride on soil Enzyme activities, Respiration and Nitrification. J Pest Sci 7:101-110.

[24] Ismail, B.S., Yapp, K.F., Omar, O., 1998. Effects of metsulfuron-methyl on amylase, urease and protease activities in two soils. Aust J Soil Res 36:449-456.

[25] Rasool, N., Reshi, Z.A., 2010. Effect of the fungicide Mancozeb at different application rates on enzyme activities in a silt loam of the Kashmir Himalaya. India. Trop Ecol 51:199-205.

[26] Masko, A.A., Lovehii, N.F., Pototskaya, L.A., 1991. Stability of immobilized soil enzymes and their role in the degradation of herbicides. Vestsi Akad. Navuk BSSR, Ser. Biyal. Navuk 5:47-51.

[27] Renella, G., M. Mench, A. Gelsomino, L. Landi and P. Nannipieri. 2005. Functional activity and microbial community structure in soils amended with bimetallic sludges. Soil Biology and Biochemistry 37: 1498-1506.

[28] Yu, Y.L., Shan, M., Fang, H., Wang, X., Chu, X.Q., 2006. Responses of Soil Microorganisms and Enzymes to Repeated Applications of Chlorothalonil. J Agric Food Chem 54:10070-10075.

[29] Caceres, T., He, W., Megharaj, M., Naidu, R., 2009. Effect of insecticide fenamiphos on soil microbial activities in Australian and Ecuadorean Soils. J Environ Sci Heal, Part B. 44:13-17.

[30] Yang, C., Sun, T., He, W., Chen, S., 2006. Effects of pesticides on soil urease activity. Ying Yong Sheng Tai Xue Bao 17:1354-1356.

[31] Tu, C.M., 1995. Effect of five insecticides on microbial and enzymatic activities in sandy soil. J Environ Sci Heal, part B. Pesticides, food contaminants, and agricultural wastes. 30: 289-306.

[32] Lodhi, A., Malik, N.N., Mahmood, T., Azam, F., 2000. Response of Soil Microflora, Microbial biomass and some Soil Enzymes to Baythroid (An insecticide). Pak J Biol Sci 3:868-871.

[33] Jastrzebska, E., Kucharski, J., 2007. Dehydrogenases, urease and phosphatases activities of soil contaminated with fungicides. Plant Soil Environ 53:51-57.

[34] Singh, D.K., Kumar, S., 2008. Nitrate reductase, arginine deaminase, urease and dehydrogenase activities in natural soil (ridges with forest) and in cotton soil after acetamiprid treatments. Chemosphere 71:412-418.

[35] Ingram, C.W., Coyne, M.S., Williams, D.W., 2005. Effects of commercial diazinon and imidacloprid on microbial urease activity in soil and sod. J Environ Qual 34:1573-1580.

[36] Bielinska, E.J., Pranagal, J., 2007. Enzymatic Activity of Soil Contaminated with Triazine Herbicides. Pol J Environ Stud 16:295-300.

[37] Chaperon, S. and S. Sauve. 2007. Toxicity interaction of metals $(\mathrm{Ag}, \mathrm{Cu}, \mathrm{Hg}, \mathrm{Zn})$ to urease and dehydrogenase activities in soils. Soil Biology and Biochemistry 39: 2329-2338.

[38] Perrin-Ganier, C., Schiavon, F., Morel, J.L., Schiavon, M., 2001. Effect of sludge amendment or nutrient in the biodegradation of the herbicide isoproturon in soil. Chemosphere 44:887-892.

[39] Krutz, L.J., Senseman, S.A., Haney, R.I., 2003. Effect of Roundup Ultra on atrazine degradation in soil. Biol Fertil Soils 38:115-118.

[40] Frankenberger, W.T., Johanson, J.B., 1982. Effect of pH on enzyme stability in soils. Soil Biol Biochem 14:433-437.

[41] Acosta-Martinez, V., Tabatabai, M.A., 2000. Enzyme activities in a limed agricultural soil. Biol Fert Soils 31:85-91.

[42] Aon, M.A., Colaneri, A.C., 2001. Temporal and spatial evolution of enzymatic activities and physicochemical 
properties in an agricultural soil. Appl Soil Ecol 18:255-270.

[43] Omar, S.A. and M.A. Abdel-Sater. 2001. Microbial populations and Enzyme Activities in Soil Treated with pesticides. Water, Air and Soil Pollution 127: 49-63.

[44] Yao, X., Min, H., Lu, Z., Yuan, H., 2006. Influence of acetamiprid on Soil enzymatic activities and respiration. Euro J Soil Biol 42:120-126.

[45] Sikora, L.J., Kaufman, D.D., Horng, L.C., 1990. Enzyme activity in soils showing enhanced degradation of organophosphate insecticides. Biol Fertil Soils 9:14-18.

[46] Kalam, A., Tah, J., Mukherjee, A.K., 2004. Pesticide effects on microbial population and soil enzyme activities during vermicomposting of agricultural waste. J Environ Biol 25:201-208

[47] Pozo, C., Martinez-Toledo, M.V., 1995. Effect of chloropyrifos on Soil microbial activity. Environ Toxicol Chem 14:187-192.

[48] Joseph, D., Adolphe, M., Thomas, N., Samuel, M.F., Moise,
N., Serges, H.Z.T., Norbert, K., 2004. Changes in soil chemical properties and microbial activities in response to the fungicide Ridomil Gold Plus Copper. Int J Environ Res Public Heal 1:26-34.

[49] Chen, S.K., Edwards, C.A., Subler, S., 2001. Effects of the fungicides benomyl, captan and chlorothalonil on soil microbial activity and nitrogen dynamics in laboratory incubations. Soil Biol Biochem 33:1971-1980.

[50] Tarafdar, J.C., 1986. Effect of different herbicides on enzyme activity in controlling weeds in wheat. Pesticides 20:46-49.

[51] Megharaj, M., Singleton, I., Kookana, R., Naidu, R., 1999. Persistence and effects of fenamiphos to native algal populations and enzyme activities in soil. Soil Biol Biochem 31:1549-1553.

[52] Atlas, R.M., Pramer, D., Bartha, R., 1978. Assessment of pesticide effects on non-target soil microorganisms. Soil Biol Biochem 10:231-239.

[53] Hazel, A.D., Greaves, M.P., 1981. Effects of some herbicides on soil enzyme activities. Weed Res 21:205-209. 